\title{
Bionectria pseudochroleuca, a new host record on Prunus sp. in northern Thailand
}

\section{Huanraluek $\mathbf{N}^{1}$, Jayawardena $\mathrm{RS}^{1,2}$, Aluthmuhandiram JVS ${ }^{1,2,3}$, Chethana $\mathrm{KWT}^{1,2}$ and Hyde $\mathrm{KD}^{1,2,4^{*}}$}

\author{
${ }^{1}$ Center of Excellence in Fungal Research, Mae Fah Luang University, Chiang Rai 57100, Thailand \\ ${ }^{2}$ School of Science, Mae Fah Luang University, Chiang Rai 57100, Thailand \\ ${ }^{3}$ Institute of Plant and Environment Protection, Beijing Academy of Agriculture and Forestry Sciences, Beijing 100097, \\ People's Republic of China \\ 4Kunming Institute of Botany, Chinese Academy of Science, Kunming 650201, Yunnan, China
}

Huanraluek N, Jayawardena RS, Aluthmuhandiram JVS, Chethana KWT, Hyde KD 2020 Bionectria pseudochroleuca, a new host record on Prunus sp. in northern Thailand. Studies in Fungi 5(1), 358-367, Doi 10.5943/sif/5/1/17

\begin{abstract}
This study presents the first report of Bionectria pseudochroleuca (Bionectriaceae) on Prunus sp. (Rosaceae) from northern Thailand, based on both morphological characteristics and multilocus phylogenetic analyses of internal transcribe spacer (ITS) and Beta-tubulin (TUB2).
\end{abstract}

Key words - Bionectriaceae - Clonostachys - Hypocreales - Nectria - Prunus spp. - Sakura

\section{Introduction}

Bionectriaceae are commonly found in soil, on woody substrates and on other fungi (Rossman et al. 1999, Schroers 2001). Bionectria is a member of Bionectriaceae (Rossman et al. 2013, Maharachchikumbura et al. 2015, 2016) and is distinct from other genera in the family as it has characteristic ascospores and ascus morphology, but none of these are consistently found in all Bionectria species (Schroers 2001). Some species of this genus such as B. tonduzii occur on living plant material (Spegazzini 1919). The species identification remained doubtful and subsequent authors considered Bionectria as a synonym of Nectria. However, the type species B. tonduzii Speg. was never recollected, and the plant-parasitic life-style of the genus was not considered as a significant character for generic delimitation of hypocrealean fungi (Müller \& von Arx 1962, Samuels 1988). Further studies were undertaken and found that Nectria-like species are distributed in three families of Hypocreales: Hypocreaceae, Nectriaceae and Bionectriaceae (Rossman et al. 1999). Recognition of Bionectria and its link to Clonostachys is based on the similarities between perithecia of B. tonduzii and B. ochroleuca / C. rosea and related species (Dingley 1957). Bionectria pseudochroleuca (previously known as Clonostachys pseudochroleuca) are common soil fungi and isolated as endophytes, epiphytes, saprotrophs and mycoparasites (Schroers 2001, Moreira et al. 2016). Distinguishing characteristics of the species B. pseudochroleuca such as penicillate conidiophores and imbricate conidia held in columns are presented based on the asexual morphs (Schroers 2001, Rossman et al. 2013).

Sakura or cherry blossoms (Prunus spp.) are flowering plants that produce stone fruits and are widely distributed in China, Japan, Korea, Myanmar, Taiwan and Thailand. There are many fungal species associated with these plants as endophytes (Dactylaria spp. and Diaporthe spp.) and 
pathogens (Botryosphaeriaceae spp., Colletotrichum spp., Diaporthe spp., Fusarium spp. and Phomopsis spp.) (Santos \& Phillips 2009, Pérez et al. 2010, Gomes et al. 2013, Marek et al. 2013).

In this paper, we report Bionectria pseudochroleuca as the first record on Prunus spp. from northern Thailand. A description, photo-plate and phylogenetic analyses are provided for $B$. pseudochroleuca, which is a new host and geographical record.

\section{Materials \& Methods}

\section{Isolates and morphology}

\section{Sample collection, morphological examination and isolation}

A dead branch of a Prunus sp. with fungal fruiting bodies was collected at Mae Fah Luang Botanical Garden, Thailand on August 2018. The specimen was placed in a plastic bag with sterilized cotton dipped in distilled water to maintain high humidity. After one day, the specimen was surface sterilized with $70 \%$ ethanol for 1 minute, $5 \% \mathrm{NaClO}$ for 1 minute, rinsed three times in sterilized water and incubated on potato dextrose agar (PDA) at $25{ }^{\circ} \mathrm{C}$ for three days. Pure isolates on PDA plates were incubated for 7 to 10 days at $25^{\circ} \mathrm{C}$ and colony morphology was recorded. Morphological observations and capturing of digital images were made following the method in Thambugala et al. (2015). The morphological characteristics were measured by using Tarosoft ${ }^{\circledR}$ Image Frame Work software (version 0.9.7). The photomicrograph plate was prepared using Adobe Photoshop CS6 version. The culture is deposited in Mae Fah Luang University Culture Collection (MFLUCC), and the fungarium specimen is deposited in the Mae Fah Luang University Herbarium (MFLU), Thailand. Faces of Fungi (FoF) number was obtained, following Jayasiri et al. (2015).

\section{DNA extraction, PCR amplification and sequencing}

Genomic DNA was obtained from a pure culture using a Qiagen DNA extraction kit following the protocols in the manufacturer's instructions (Qiagen, USA). The polymerase chain reactions (PCR) were carried out using two partial gene regions ITS (ITS5/ITS4, White et al. 1990) and $\beta$-tubulin (BT2A/BT2B, Glass \& Donaldson 1995, O’Donnell \& Cigelnik 1997, Carbone \& Kohn 1999, Rehner 2001). The PCR was performed in a BIORAD 1000 Thermal Cycler in a total volume of $25 \mu \mathrm{l}$. PCR mixtures contained TaKaRa Ex-Taq DNA polymerase $0.3 \mu \mathrm{l}, 12.5 \mu \mathrm{l}$ of $2 \times$ PCR buffer with $2.5 \mu \mathrm{l}$ of dNTPs, $1 \mu \mathrm{l}$ of each primer, $9.2 \mu \mathrm{l}$ of double-distilled water and 100-500 ng of DNA template. Giraldo et al. (2017) was followed for the thermal cycling program. The PCR products were visualized under UV light using a GelDoc XR+ Molecular Imager (Bio-Rad, Hercules, CA, USA) on 1\% agarose electrophoresis gels stained with ethidium bromide. The PCR products were purified and sequenced at Beijing Biomed Gene Technology Co., Ltd, Beijing, China. All the newly generated sequences in this study were deposited in the GenBank (Table 1).

\section{Phylogenetic analyses}

Phylogenetic trees and data files were created from the combined ITS and TUB2 sequence dataset (Table 1). Sequence alignment of each gene partition was automatically aligned with MAFFT (v.7.310) (Katoh \& Stanley 2016) and manually aligned wherever necessary in BioEdit version v.7.0.9.1 (Hall 1999). Two separate phylogenetic trees were constructed for topology comparison. In the CIPRES Science Gateway V. 3.3 (Miller et al. 2011), RAxML rapid bootstrapping and subsequent ML search were performed using distinct model/data partitions with joint branch length optimization. Rapid bootstrap inferences were set to 1,000 and thereafter a thorough ML search was done. All free model parameters were estimated by RAxML. Likelihood of the final tree was evaluated and optimized under GAMMA +P-Invar. Model parameters were estimated to an accuracy of 0.001 log-likelihood units. Bayesian inference analysis (BYPP) was determined by using MrBayes 3.2 on XSEDE (Ronquist et al. 2011) in the CIPRES portal (Miller et al. 2011), Simultaneous Markov chains were run for 1,000,000 generations and trees were sampled every 100th generation. The first 1,000 trees, representing the burn-in phase of the 
analyses, were discarded, while the remaining trees were used for calculating posterior probabilities in the majority rule consensus tree and using Adobe Illustrator CS3 software to present the tree.

\section{Results}

\section{Phylogenetic analyses}

The final alignment included 68 strains, representing Bionectriaceae. Maximum parsimony, maximum likelihood and bayesian inferences presented similar topologies in their phylogenetic trees. The phylogenetic tree (Fig. 1) was constructed through analyses of the ITS sequence data combined with TUB2 sequence data for Bionectriaceae. Single gene analyses were carried out and the topology of the tree and clade stability were compared. The best scoring tree obtained from maximum likelihood analysis received a final value of -10139.659585. The matrix had 541 distinct alignment patterns, with $35.67 \%$ of undetermined characters or gaps. Estimated base frequencies were as follows; $\mathrm{A}=0.206628, \mathrm{C}=0.274931, \mathrm{G}=0.247047, \mathrm{~T}=0.271394$; substitution rates AC $=1.087025, \mathrm{AG}=3.019444, \mathrm{AT}=1.159304, \mathrm{CG}=0.589069, \mathrm{CT}=3.528787, \mathrm{GT}=1.000000$; gamma distribution shape parameter alpha $=0.851856$ and invar $=0.397405$. Our strain $B$. pseudochroleuca (MFLUCC 19-0491) clustered with the other strains of B. pseudochroleuca (CBS 192.94, CBS 220.93) with high bootstrap support (99\% ML/ 1.00 BYPP) confirming its phylogenetic position (Fig. 1).

\section{Bionectriaceae Samuels \& Rossman}

Bionectriaceae is found as soil inhabitants, plant decomposers and endophytes in tropical and subtropical areas (Schroers 2001, Domsch et al. 2007, Lucas et al. 2014). Both sexual and asexual morphs have been recorded for the species in this family (Rossman et al. 1999, Maharachchikumbura et al. 2015, 2016).

\section{Bionectria Speg}

Bionectria (syn. Clonostachys) (Rossman et al. 2013, Maharachchikumbura et al. 2015, 2016, Hongsanan et al. 2017), has 42 species epithets in Index Fungorum (2020). Species of this genus have found on barks of recently dead trees, decaying leaves, rarely on lichens, frequently close to or on fungal hosts, particularly ascomycetes, or with stroma incorporating a host. The asexual morphs are often associated with sexual morphs on various decaying plant materials or obtained separately when soil-borne (Schroers 2001, Rossman et al. 2013). Some species of this genus are known as destructive mycoparasites, growing on or in the host mycelium, sometimes on animal substrata (Schroers 2001). In this study, we would like to use the name Bionectria, as this name is commonly used in the plant pathology associated with trunk diseases of numerous hosts. Therefore, even though Bionectria has been synonymized to Clonostachys we would retain the use of Bionectria to avoid confusion within the plant pathology community.

Bionectria pseudochroleuca Schroers \& Samuels, Stud. Mycol. 46: 122 (2001)

Fig. 2

Index Fungorum number: IF485135; Facesoffungi number: FoF06563

Saprobic on dead branch of Prunus sp. Sexual morph: not observed. Asexual morph: secondary conidiophores $81-141 \times 2-6 \mu \mathrm{m}(\overline{\mathrm{x}}=101 \times 3 \mu \mathrm{m}, \mathrm{n}=6)$, solitary or aggregated, arising from strands of aerial mycelium or directly from medium, bi- to quarter verticillate terminating in moderately divergent metulate and adpressed phialides. Phialides 9-24 $2-3 \mu \mathrm{m}(\overline{\mathrm{x}}=15 \times 2 \mu \mathrm{m}, \mathrm{n}$ $=3$ ), in whorls of $2-6$, almost cylindrical tapering in upper part, straight to slightly curved. Conidia 4-6 $\times 2-3 \mu \mathrm{m}(\overline{\mathrm{x}}=5 \times 3 \mu \mathrm{m}, \mathrm{n}=10)$, formed by phialides on secondary conidiophores hyaline, ellipsoidal, slightly curved with one almost straight side, hilum typically laterally displaced.

Culture characteristics - Colonies reaching $25 \mathrm{~mm}$ diam in 16 days at $25{ }^{\circ} \mathrm{C}$ on PDA colony reverse yellowish white or pale white. 
Material examined - THAILAND, Chiang Rai Province, Mae Fah Luang Botanical Garden, on dead branch of Prunus sp. (Rosaceae), 21 August 2018, Ruvishika S. Jayawardena, Fungarium no: MFLU 19-2644, Culture collection no: MFLUCC 19-0491.

\section{Bionectriaceae}

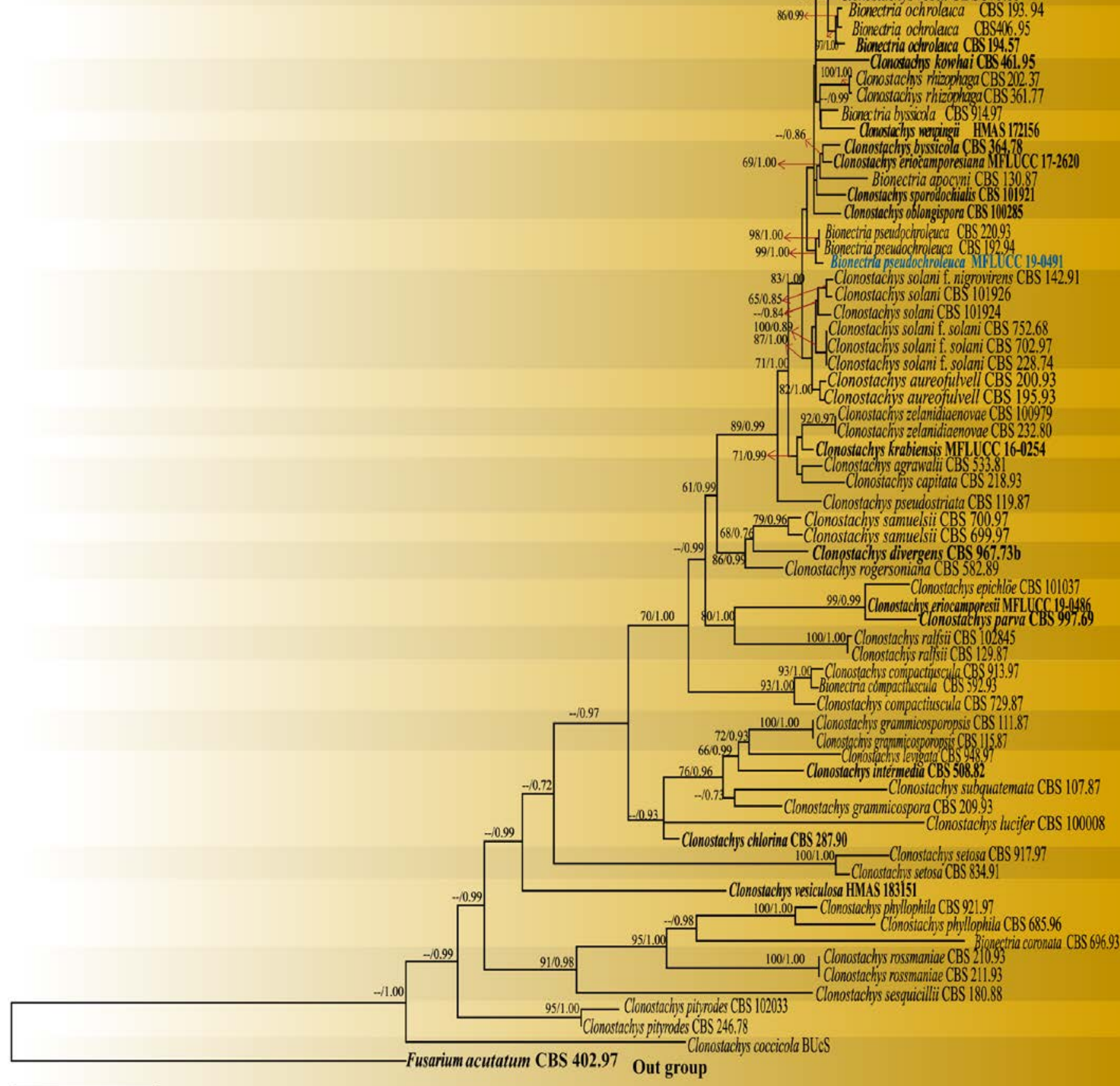

0.1

Fig. 1 - Phylogram generated from maximum likelihood analysis of combined ITS and TUB sequence data of the family Bionectriaceae. Bootstrap (ML/BYPP) support values greater than or equal $60 \%$ are given above the nodes. Culture accession number is given along with the species name, and the tree is rooted to Fusarium acutatum (CBS 402.97). Our stain is in blue bold and extypes are in black bold. 
Table 1 GenBank accession numbers, culture accession numbers, host information and countries reported of the taxa used in the phylogenetic analyses. Sequences generated in this study are in blue bold and ex-type strains are in black bold.

\begin{tabular}{|c|c|c|c|c|c|}
\hline \multirow[t]{2}{*}{ Taxa names } & \multirow{2}{*}{$\begin{array}{l}\text { Culture } \\
\text { collection }\end{array}$} & \multirow[t]{2}{*}{ Host } & \multirow[t]{2}{*}{ Country } & \multicolumn{2}{|c|}{ GenBank accession numbers } \\
\hline & & & & ITS & TUB \\
\hline Bionectria apocyni & CBS 130.87 & dead stem of Apocynum cannabinum & U.S.A, New York & AF210688 & AF358168 \\
\hline Bionectria byssicola & CBS 914.97 & Alchorea branches & Uganda & AF358252 & AF358151 \\
\hline Bionectria compactiuscula & CBS 592.93 & bark of Fagus sp. & France & AF358247 & AF358192 \\
\hline Bionectria coronata & CBS 696.93 & leaves of Buxus sempervirens & France & AF210667 & AF358215 \\
\hline Bionectria ochroleuca & CBS 193.94 & live rachis of Pteridium aquilinum & Guyana & AF210686 & AF358159 \\
\hline Bionectria ochroleuca & CBS 406.95 & bark of Salix sp. & France & AF358249 & AF358167 \\
\hline Bionectria ochroleuca & CBS 194.57 & decaying bulb of Lilium auratum & U.S.A & AF358237 & AF358165 \\
\hline Bionectria pseudochroleuca & CBS 192.94 & decaying palm & French Guiana & AF358238 & AF358171 \\
\hline Bionectria pseudochroleuca & CBS 220.93 & palm & French Guiana & - & AF358172 \\
\hline Bionectria pseudochroleuca & $\begin{array}{l}\text { MFLUCC 19- } \\
0491\end{array}$ & Prunus sp. & $\begin{array}{l}\text { Chiang Rai, } \\
\text { Thailand }\end{array}$ & MN647544 & MN688570 \\
\hline Clonostachys agrawalii & CBS 533.81 & $\begin{array}{l}\text { decomposing buffalo horn from animal house } \\
\text { floor sweepings }\end{array}$ & India & AF358241 & AF358187 \\
\hline Clonostachys aureofulvella & CBS 195.93 & root of tree unknown host & New Zealand & AF358226 & AF358181 \\
\hline Clonostachys aureofulvella & CBS 200.93 & palm & French Guiana & - & AF358182 \\
\hline Clonostachys byssicola & CBS 364.78 & wood & Venezuela & MH861151 & AF358153 \\
\hline Clonostachys capitata & CBS 218.93 & bark unknown host & Japan & AF358240 & AF358188 \\
\hline Clonostachys chlorina & CBS 287.90 & soil & Brazil & MH862212 & - \\
\hline Clonostachys coccicola & BUcS & Unaspis citri & Australia & KU720552 & - \\
\hline Clonostachys compactiuscula & CBS 913.97 & bark of dead Fagus sp. & $\begin{array}{l}\text { U.S.A., North } \\
\text { Carolina }\end{array}$ & AF358245 & AF358194 \\
\hline Clonostachys compactiuscula & CBS 729.87 & soil & Germany & AF358242 & AF358193 \\
\hline Clonostachys divergens & CBS 967.73b & soil & Germany & AF210677 & AF358191 \\
\hline Clonostachys epichloë & CBS 101037 & Sasa sp. & Japan & AF210675 & AF358209 \\
\hline $\begin{array}{l}\text { Clonostachys } \\
\text { eriocamporesiana }\end{array}$ & $\begin{array}{l}\text { MFLUCC 17- } \\
2620\end{array}$ & Botryosphaeriaceae & Thailand & MN699132 & MN699965 \\
\hline Clonostachys eriocamporesii & $\begin{array}{l}\text { MFLUCC 19- } \\
0486\end{array}$ & Cenchrus polystachios & Thailand & MN699133 & - \\
\hline Clonostachys grammicospora & CBS 209.93 & standing dead tree & French Guiana & AF210678 & AF358206 \\
\hline $\begin{array}{l}\text { Clonostachys } \\
\text { gramnicosporopsis }\end{array}$ & CBS 111.87 & bark of Coprosma sp. & New Zealand & AF358255 & - \\
\hline $\begin{array}{l}\text { Clonostachys } \\
\text { grammicosporopsis }\end{array}$ & CBS 115.87 & bark of Metrosideros sp. & New Zealand & AF210679 & AF358204 \\
\hline Clonostachys intermedia & CBS 508.82 & soil & Netherlands & AF210682 & AF358205 \\
\hline
\end{tabular}


Table 1 Continued.

\begin{tabular}{|c|c|c|c|c|c|}
\hline \multirow[t]{2}{*}{ Species } & \multirow{2}{*}{$\begin{array}{l}\text { Culture } \\
\text { collection }\end{array}$} & \multirow[t]{2}{*}{ Host } & \multirow[t]{2}{*}{ Country } & \multicolumn{2}{|c|}{ GenBank accession numbers } \\
\hline & & & & ITS & TUB \\
\hline Clonostachys kowhaii & CBS 461.95 & bark of Sophora microphylla & New Zealand & AF358250 & AF358170 \\
\hline Clonostachys krabiensis & $\begin{array}{l}\text { MFLUCC 16- } \\
0254\end{array}$ & Pandanaceae & Thailand & MH388335 & - \\
\hline Clonostachys levigata & CBS 948.97 & branch of dead Buxus sempervirens & France & AF210680 & AF358196 \\
\hline Clonostachys lucifer & CBS 100008 & Bark of recently dead Casearia arborea & U.S.A., Puerto Rico & AF210683 & AF358208 \\
\hline Clonostachys oblongispora & CBS 100285 & bark of dying tree of Orixa japonica & Japan & AF358248 & AF358169 \\
\hline Clonostachys parva & CBS 997.69 & soil & Netherlands & AF210677 & AF358210 \\
\hline Clonostachys phyllophila & CBS 685.96 & - & Cuba & AF210663 & - \\
\hline Clonostachys phyllophila & CBS 921.97 & leaves of Viscum album & France & AF210664 & - \\
\hline Clonostachys pityrodes & CBS 246.78 & bark & Brazil & AF210673 & - \\
\hline Clonostachys pityrodes & CBS 102033 & bark & Mauritius & AF210672 & AF358212 \\
\hline Clonostachys pseudostriata & CBS 119.87 & bark & Indonesia & AF358251 & AF358183 \\
\hline Clonostachys ralfsii & CBS 129.87 & bark & New Zealand & AF210676 & AF358195 \\
\hline Clonostachys ralfsii & CBS 102845 & bark & Australia, Victoria & AF358253 & AF358219 \\
\hline Clonostachys rhizophaga & CBS 202.37 & root of Ulmus americana & U.S.A., Ohio & AF358225 & AF358156 \\
\hline Clonostachys rhizophaga & CBS 361.77 & culture contaminant & Switzerland & AF358228 & AF358158 \\
\hline Clonostachys rogersoniana & CBS 582.89 & soil & Brazil & AF210691 & AF358189 \\
\hline Clonostachys rosea & CBS 376.55 & on Acer palmatum & U.S.A., Massachusett & MH857520 & AF358162 \\
\hline Clonostachys rosea & CBS 710.86 & soil, on sclerotia of Sclerotinia minor & Netherlands & MH862010 & - \\
\hline $\begin{array}{l}\text { Clonostachys rosea } \mathrm{f} . \\
\text { catenulata }\end{array}$ & CBS 154.27 & soil & U.S.A., Utah & MH854911 & AF358160 \\
\hline $\begin{array}{l}\text { Clonostachys rosea } \mathrm{f} . \\
\text { catenulata }\end{array}$ & CBS 221.72b & soil & Germany & AF358234 & AF358203 \\
\hline $\begin{array}{l}\text { Clonostachys rosea } \mathrm{f} . \\
\text { catenulata }\end{array}$ & CBS 443.65 & soil & U.S.A., Wyoming & MH858662 & AF358166 \\
\hline $\begin{array}{l}\text { Clonostachys rosea } \mathrm{f} . \\
\text { nigrovirens }\end{array}$ & CBS 142.91 & egg of Arion ater & Germany & AF358244 & AF358178 \\
\hline Clonostachys rossmaniae & CBS 210.93 & bark of twigs & French Guiana & AF358227 & AF358213 \\
\hline Clonostachys rossmaniae & CBS 211.93 & bark of living liana & French Guiana & MH862393 & - \\
\hline Clonostachys samuelsii & CBS 699.97 & bark & Venezuela & AF358236 & AF358190 \\
\hline Clonostachys samuelsii & CBS 700.97 & bark & U.S.A., Puerto Rico & AF210689 & - \\
\hline Clonostachys sesquicillii & CBS 180.88 & twigs and lichen & Guyana & AF210666 & AF358214 \\
\hline Clonostachys setosa & CBS 834.91 & Trophis racemose & Cuba & AF210670 & AF358211 \\
\hline Clonostachys setosa & CBS 917.97 & decaying twig & U.S.A., Puerto Rico & MH862683 & - \\
\hline
\end{tabular}


Table 1 Continued.

\begin{tabular}{|c|c|c|c|c|c|}
\hline \multirow[t]{2}{*}{ Species } & \multirow{2}{*}{$\begin{array}{l}\text { Culture } \\
\text { collection }\end{array}$} & \multirow[t]{2}{*}{ Host } & \multirow[t]{2}{*}{ Country } & \multicolumn{2}{|c|}{ GenBank accession numbers } \\
\hline & & & & ITS & TUB \\
\hline Clonostachys solani & CBS 101924 & Hypoxylon sp. on bark & Jamaica & AF358232 & AF358180 \\
\hline Clonostachys solani & CBS 101926 & decaying palm inflorescence & Venezuela & AF358230 & AF358179 \\
\hline Clonostachys solani f. solani & CBS 228.74 & tuber of Solanum tuberosum & Netherlands & AF358243 & - \\
\hline Clonostachys solani f. solani & CBS 702.97 & rotten fruit of Aesculus hippocastanum & France & AF210687 & AF358177 \\
\hline Clonostachys solani f. solani & CBS 752.68 & bark & Germany & AF358246 & AF358221 \\
\hline Clonostachys sporodochialis & CBS 101921 & bark & U.S.A., Puerto Rico & AF210685 & AF358149 \\
\hline Clonostachys subquatemata & CBS 107.87 & wood & Venezuela & - & AF358207 \\
\hline Clonostachys vesiculosa & HMAS 183151 & - & China & HМ050304 & - \\
\hline Clonostachys wenpingii & HMAS 172156 & - & - & NR_119651 & HM054127 \\
\hline $\begin{array}{l}\text { Clonostachys } \\
\text { zelanidiaenovae }\end{array}$ & CBS 232.80 & bark of Coprosma sp. & New Zealand & AF210684 & AF358185 \\
\hline $\begin{array}{l}\text { Clonostachys } \\
\text { zelanidiaenovae }\end{array}$ & CBS 100979 & bark of Agathis australis & New Zealand & AF358229 & - \\
\hline $\begin{array}{l}\text { Fusarium acutatum } \\
\text { (outgroup) }\end{array}$ & CBS 402.97 & - & India & MH862652 & KU603870 \\
\hline
\end{tabular}

\section{Discussion}

A blast search in NCBI of our strain (MFLUCC 19-0491) showed 92.71\% similarity to Clonostachys sp. (MH421858) in ITS and 98.31\% similarity to Bionectria pseudochroleuca (FJ904909) in TUB2 gene regions. In the phylogenetic tree, our strain, B. pseudochroleuca (MFLUCC 190491) clustered with B. pseudochroleuca (CBS 192.94), (CBS 220.93) with high support (99\% ML/1.00 BYPP). Our strain formed colonies with secondary conidiophores after 16 days, which is similar to the type strain of $B$. pseudochroleuca. However, our strain did not produce bright yellow to greenish yellow pigment on media, which was observed in the ex-type culture of this species (Moreira et al. 2016). There are only two records for the occurrence of Bionectria on Prunus spp. in the U.S. National Fungus Collections Fungus-Host Database (USDA, Farr \& Rossman 2019). Bionectria orcholeuca has been recorded from Prunus persica in New Zealand (Gadgil 2005) and B. sporodochialis from P. jamasakura in Japan (Hirooka \& Kobayashi 2007). In Thailand, six fungal species have been identified associated with Prunus spp. so far (Farr \& Rossman 2019): Apiosordaria striatispora (P. arborea, Hyde et al. 1997), Neofusicoccum parvum (P. cerasoides, Trakunyingcharoen et al. 2015), Passalora rubrotincta (causing leaf spot of $P$. persica, Giatgong 1980), Phyllosticta capotalensis (P. cerasoides, Okane et al. 2003), Podosphaera sp. (P. mume, P. persica, Meeboon et al. 2016) and Tranzchelia pruni-spinosae (P. persica, Lorsuwan 1984). Therefore, to our knowledge this study provides the first host and geographical record of B. pseudochroleuca associated with Prunus spp. in Thailand. 

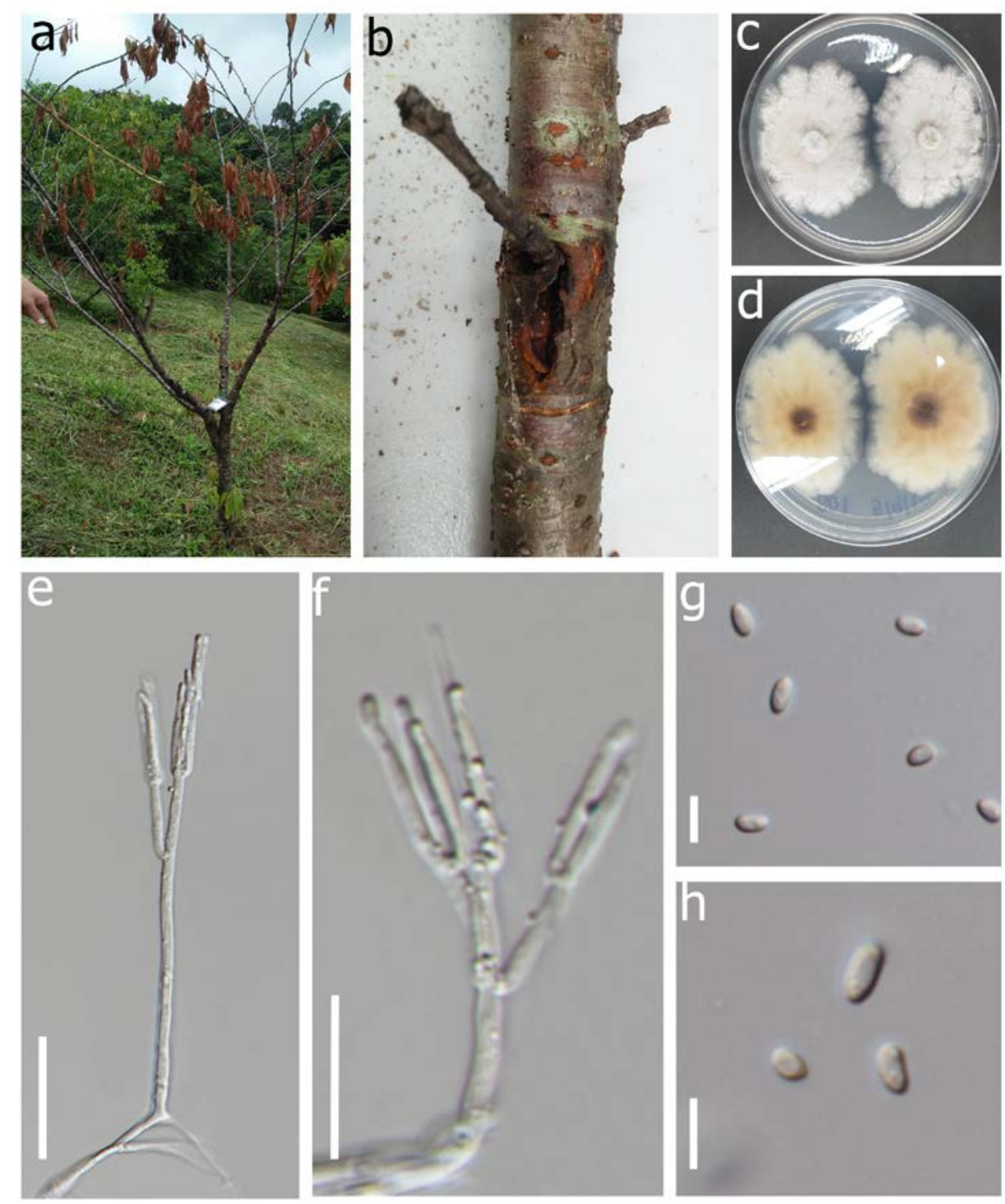

Fig. 2 - Bionectria pseudochroleuca. a-b Appearance on host surface. c, d Colonies on PDA 16 days old incubated at $25^{\circ} \mathrm{C}$. e, f Secondary conidiophores with appressed branches and Phialides. g, h Conidia. Scale bars: $\mathrm{e}-\mathrm{f}=20 \mu \mathrm{m}, \mathrm{g}-\mathrm{h}=5 \mu \mathrm{m}$.

\section{Acknowledgements}

The authors would like to thank the Mae Fah Luang University Botanical garden director J. Tovaranonte and the botanist A. Songssangchun for help with collecting the samples. Authors would like to thank the Mae Fah Luang University for providing financial support for the research work and Kevin D. Hyde would like to thank the grants entitled: 1 . The future of specialist fungi in a changing climate: baseline data for generalist and specialist fungi associated with ants, Rhododendron species and Dracaena species (Grant number: DBG6080013); 2. Impact of climate change on fungal diversity and biogeography in the Greater Mekong Subregion (Grant number: RDG6130001).

\section{References}

Carbone I, Kohn LM. 1999 - A method for designing primer sets for speciation studies in filamentous ascomycetes. Mycologia 91, 553-556.

Dingley JM. 1957 - Life history studies in the genus Hypocrea. Transactions and Proceedings of the Royal Society of New Zealand 84, 689-693. 
Domsch KH, Gams W, Anderson T. 2007 - Compendium of soil fungi, 2nd edn. IHW Verlag, Eching.

Farr DF, Rossman AY. 2019 - Fungal Databases, U.S. National Fungus Collections, ARS, USDA.

Gadgil PD. 2005 - Fungi on trees and shrubs in New Zealand. Fungi of New Zealand (Volume 4). Fungal Diversity Press, Hong Kong, 437 pages.

Giatgong P. 1980 - Host Index of Plant Diseases in Thailand. Second Edition. Mycology Branch, Plant Pathology and Microbiology Division, Department of Agriculture and Cooperatives, Bangkok, Thailand.118.

Giraldo A, Gené J, Sutton DA, Wiederhold N, Guarro J. 2017 - New acremonium-like species in the Bionectriaceae and Plectosphaerellaceae. Mycological Progress 16, 349-368.

Glass NL, Donaldson GC. 1995 - Development of primer sets designed for use with the PCR to amplify conserved genes from filamentous ascomycetes. Applied and Environmental Microbiology 61, 1323-1330.

Gomes RR, Glienke C, Videira SIR, Lombard L et al. 2013 - Diaporthe: a genus of endophytic, saprobic and plant pathogenic fungi. Persoonia 31, 1-41.

Hall TA. 1999 - BioEdit: A user-friendly biological sequence alignment editor and analysis program for Windows 95/98/NT. Nucleic Acids Symposium Series 41, 95-98.

Hirooka Y, Kobayashi T. 2007 - Taxonomic studies of nectrioid fungi in Japan. II: The genus Bionectria. Mycoscience 48, 81-89.

Hongsanan S, Maharachchikumbura SSN, Hyde KD, Samarakoon MC et al. 2017 - An updated phylogeny of Sordariomycetes based on phylogenetic and molecular clock evidence. Fungal Diversity 84, 25-41.

Hyde KD, Wong SW, Lumyong S, Lumyong P. 1997 - Apiosordaria striatispora, an endophyte of Mesua ferrea and Prunus arborea from Thailand. Mycoscience 38, 437-439.

Index Fungorum 2020 - http://www.indexfungorumorg/Names/Namesasp

Jayasiri SC, Hyde KD, Ariyawansa HA, Bhat J et al. 2015 - The Faces of Fungi database: fungal names linked with morphology, phylogeny and human impacts. Fungal diversity 74, 3-18.

Katoh K, Standley DM. 2016 - MAFFT multiple sequence alignment software version 7: improvements in performance and usability. Molecular Biology and Evolution 30, 772-780.

Lorsuwan C, Tontyaporn S, Visarathanonth N, Manoch L, Kakishima M. 1984 - Materials for the rust flora in Thailand I. Transactions of the British Mycological Society. Japan 25, 57-65.

Lucas MA, Gláucia MM, Douglas F, Edson RF, Ludwig HP. 2014 - Diversity of Clonostachys species assessed by molecular phylogenetics and MALDI-TOF mass spectrometry. The British Mycological Society. 1004-1012.

Maharachchikumbura SSN, Hyde KD, Gareth Jones EB, McKenzie EHC et al. 2015 - Towards a natural classification and backbone tree for Sordariomycetes. Fungal Diversity 72, 199-301.

Maharachchikumbura SSN, Hyde KD, Gareth Jones EB, McKenzie EHC et al. 2016 - Families of Sordariomycetes. Fungal Diversity 79, 1-317.

Marek SM, Yaghmour MA, Bostock RM. 2013 - Fusarium spp., Cylindrocarpon spp., and environmental stress in the etiology of a canker disease of cold-stored fruit and nut tree seedlings in California. Plant Disease 97, 259-270.

Meeboon J, Hidayat I, Takamatsu S. 2016 - Notes on powdery mildews (Erysiphales) in Thailand I. Podosphaera sect. Sphaerotheca. Pl. Pathol \& Quarantine 6, 142-174.

Miller MA, Pfeiffer W, Schwartz T. 2011 - Creating the CIPRES Science Gateway for inference of large phylogenetic trees. Proceedings of the Gateway Computing Environments Workshop (GCE). New Orleans, LA. CA, San Diego Supercomputer. Center, pp. 1-8.

Moreira GM, Abreu LM, Carvalho VG, Schroers H-J, Pfenning LH. 2016 - Multilocus phylogeny of Clonostachys subgenus Bionectria from Brazil and description of Clonostachys chloroleuca sp. nov. Mycological Progress 15, 1031-1039.

Müller E, von Arx JA. 1962 - Die Gattungen der didymosporen Pyrenomyceten. Beitr Kryptogamenflora Schweiz 11, 1-922. 
O’Donnell K, Cigelnik E. 1997 - Two divergent intragenomic rDNA ITS2 types within a monophyletic lineage of the fungus Fusarium are nonorthologous. Molecular Phylogenetics and Evolution 7, 103-116.

Okane I, Lumyong S, Nakagiri A, Ito T. 2003 - Extensive host range of an endophytic fungus, Guignardia endophyllicola (anamorph: Phyllosticta capitalensis). Mycoscience 44, 353-363.

Pérez CA, Wingfield MJ, Slippers B, Altier NA, Blanchette RA. 2010 - Endophytic and cankerassociated Botryosphaeriaceae occurring on non-native Eucalyptus and native Myrtaceae trees in Uruguay. Fungal Diversity 41, 53-69.

Rehner SA. 2001 - Primers for Elongation Factor 1-alpha (EF1-alpha). http://ocid.nacse.org/research/deephyphae/EF1primer.pdf.

Ronquist F, Huelsenbeck J, Teslenko M. 2011 - Draft MrBayes version 3.2. Manual: tutorials and model summaries. Bioinformatics 85-131.

Rossman AY, Samuels GJ, Rogerson CT, Lowen R. 1999 - Genera of Bionectriaceae, Hypocreaceae and Nectriaceae (Hypocreales, Ascomycetes). Studies in Mycology 42-238.

Rossman AY, Seifert KA, Samuels GJ, Minnis AM et al. 2013 - Generain Bionectriaceae, Hypocreaceae, and Nectriaceae (Hypocreales) proposed for acceptance or rejection. IMA Fungus 4, 41-51.

Samuels GJ. 1988 - Fungicolous, lichenicolous, and myxomyceticolous species of Hypocreopsis, Nectriopsis, Nectria, Peristomialis, and Trichonectria. Memoirs of the New York Botanical Garden. 48, 1-78.

Santos JM, Phillips AJL. 2009 - Resolving the complex of Diaporthe (Phomopsis) species occurring on Foeniculum vulgare in Portugal. Fungal diversity 34, 111-125.

Schroers H-J. 2001 - A monograph of Bionectria (Ascomycota, Hypocreales, Bionectriaceae) and its Clonostachys anamorphs. Studies in Mycology 46, 1-214.

Spegazzini C. 1919 - Fungi Costaricenses nonnulli. Bol Acad Nac Cienc 579, 541-609.

Thambugala KM, Hyde KD, Tanaka K, Tian Q et al. 2015 - Towards a natural classification and backbone tree for Lophiostomataceae, Floricolaceae, and Amorosiaceae fam. nov. Fungal Diversity 74, 199-266.

Trakunyingcharoen T, Lombard L, Groenewald JZ, Cheewangkoon R et al. 2015 - Caulicolous Botryosphaeriales from Thailand. Persoonia 34, 87-99.

White TJ, Bruns T, Lee S, Taylor J. 1990 - Amplification and direct sequencing of fungal ribosomal RNA genes for phylogenetics. In: Innis, MA, Gelfand, DH, Sninsky, JJ. \& White, TJ. (Eds.) PCR protocols: a guide to methods and applications. Academic Press, New York, pp. 315-322. 